The Face of the Earth 



\section{The Face of the Earth}

Natural Landscapes, Science, and Culture

\section{SueEllen Campbell}

with Alex Hunt, Richard Kerridge,

Tom Lynch, and Ellen Wohl

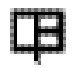

UNIVERSITY OF CALIFORNIA PRESS

Berkeley • Los Angeles • London 
University of California Press, one of the most distinguished university presses in the United States, enriches lives around the world by advancing scholarship in the humanities, social sciences, and natural sciences. Its activities are supported by the UC Press Foundation and by philanthropic contributions from individuals and institutions. For more information, visit www.ucpress.edu.

University of California Press

Berkeley and Los Angeles, California

University of California Press, Ltd.

London, England

(C) 201 I by The Regents of the University of California

Library of Congress Cataloging-in-Publication Data

Campbell, SueEllen.

The face of the Earth : natural landscapes, science, and culture / Sue Ellen Campbell ; with Alex Hunt... [et al.].

p. $\mathrm{cm}$.

Includes bibliographical references and index.

ISBN 978-0-520-26926-2 (cloth : alk. paper)

ISBN 978-0-520-26927-9 (pbk. : alk. paper)

I. Nature and civilization. 2. Natural history.

I. Title.

CB460.C36 2OII

$508-\mathrm{de} 22$

2010052469

Manufactured in the United States of America

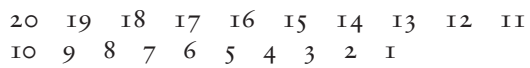

In keeping with a commitment to support environmentally responsible and sustainable printing practices, UC Press has printed this book on Rolland Enviro Ioo, a Io०\% post-consumer fiber paper that is FSC certified, deinked, processed chlorine-free, and manufactured with renewable biogas energy. It is acid-free and EcoLogo certified. 